\title{
'MUSIC OF ORIGIN': \\ CLASS, SOCIAL CATEGORY AND THE PERFORMERS AND AUDIENCE OF KIBA, A SOUTH AFRICAN MIGRANT GENRE
}

\author{
Deborah James
}

Much of the writing on performance and audience, from that covering oral genres in a barely literate Africa to that analysing the listenership and readership of major newspapers and television stations, is underpinned by the idea that specific genres of expressive culture are aimed at, and usually reach, particular target groups. In the work of writers on the media in particular, this idea often carries with it the assumption that the work of a broadcast is one-sided and that there is little chance of a proactive role for listeners or audience (Barnard, 1989; Chambers, 1986).

The implications of this view are most far-reaching if one looks at media interventions in music and culture. Some writers on South African popular culture, for example, while allowing that there is a degree of creative interaction between performers and audience where performance is live, have been less willing to acknowledge this where it is transmitted via the media (Ballantine, 1993; see Meintjes, 1996). This approach leads almost automatically to the conclusion that media dissemination of music facilitates hegemonic control over a passive populace.

My concern in the present article is with a genre-kiba-which has been more often performed and appreciated live than disseminated via the broadcasting and recording industries. Nevertheless, it is instructive to begin with a short account of a controversy over the role of media audiences which briefly engaged the energies of writers in South Africa. A look at this debate indicates that the social stratification implied by the article's title was initially overlooked, and sets the scene for a more subtle understanding. (One of the constituencies of listeners which these writers initially ignored corresponds, incidentally, with the class from which kiba's primary audience is drawn.)

Writers on the South African media have seen state and capital as attempting to manipulate listeners' and audiences' tastes in a bid to deny the emergence of a permanently urbanised black population, and to promote instead the vision of a rurally rooted migrant labour force. A variety of musics were promoted by media and management during the 1950s and 1960s to bolster this vision: either syncretic forms played by rural musicians or those more thoroughly indigenous in style, but both beamed at audiences with specific ethnic origins (Coplan, 1979: 198, 206-7; Ballantine, 1989: 308). The music was thought of as 'traditional' by its media propagators-a term which, to critics, evokes the futility of the state's pretence that black people by the 1950 s and 1960 s were still country-dwellers primarily oriented to customary ways rather than townsmen accustomed to a sophisticated city life and favouring jazz as a means of cultural expression. 
Seen from this critical perspective, the state manipulated traditional or neo-traditional music in order to implement - or, at its most futile, to claim an illusory success for-its policy of keeping Africans as residents of ethnic reserves rather than allowing them to become city-dwellers. But evidence can be found that urban African identity in this period was already considerably divided, and that there was a large body of listeners-primarily migrant, domestic and industrial labourers (Coplan, 1979: 207)-who did prefer to participate in rural styles, or to listen to the 'neo-traditional' instrumental and vocal jive which the media were disseminating (Hamm, 1987: 354). If stratification within the urban-based African populace was already well developed, then the choice of music broadcast by the SABC's ethnic radio stations was, at least partly, dictated by the preference of one of its groups of listeners.

In this debate over the role of the media in South Africa the influence of early British cultural studies and of Frankfurt school writers such as Adorno can be plainly seen, while the contrasting approach which emphasises the ability of consumers to appropriate commodities and integrate them into 'subjectively motivated social practice' (Middleton, 1986: 139) appears only barely to have made its mark. In the case of radio jive music in South Africa, then, the observation that specific types of expressive culture are beamed at specific target groups is accurate but tells us only half the story. Practice theory insists that the very act of performance plays a socially constitutive role and that musical and dance genres, rather than merely mirroring the predilections of established groupings of people, may also create new social situations: that players and audience may constitute themselves as groups in the process of enacting or appreciating a performance. Seen in this light, the fostering and broadcasting of radio jive may have played a formative role: not in claiming the illusory existence of or hegemonically creating a previously non-existent migrant underclass, but in furnishing a nexus of identification for the inchoate and emerging group of illiterate and unskilled workers who were its players and its intended audience.

Thus a performance which, on one level, has a profoundly divisive effect by distinguishing between the members of different social categories or classes, can on another level transcend these divisions. 'Popular culture', with its primarily urban constituency and syncretic nature, is the form which has been identified as doing this most completely. Genres created in the process of urbanisation, such as South African marabi, played a key role in articulating-indeed, in bringing into being-new identities transcending people's divided and parochial origins (Coplan, 1985: 105-9; Barber, 1987: 58-9). And the expressive acts of popular culture have blurred the boundaries between classes as well as between people from distinct ethnic origins. In Natal, for example, where emergent classes were salient in the social and musical histories of Pietermaritzburg and Durban, the osmosis of musical style and influence between them was so pervasive (Erlmann, 1991), and the activities of cultural brokers who strutted disdainfully from one to the other and back again so influential (La Hausse, 1993), as to undermine completely the notion of a class as a concrete social category.

These emergent, shifting and blurred identities, partly created in and through performance, call into question the hard-and-fast categorisations in 
terms of class that have characterised some South African scholarship. But it is not only within studies of popular culture that the notion of class is being called into question. Once the single most important instrument in the conceptual tool kit of social historians in South Africa, the idea of class is now seen to have been based, inappropriately, on Western/universalist assumptions of the inevitability of progress, and to have imposed a 'uniform, homogenized, extrahistorical subjectivity' upon working - and by implication non-working - people in all corners of the globe (Chakrabarty, 1989: 223; Joyce, 1995).

These claims may seem a little unfair, since the more subtle writings on the proletarianisation of the South African labour force did acknowledge the complexity of class formation, and did demonstrate that movement from the countryside to town was often dictated as much by local imperatives-by indigenous considerations of gender or regional alliance-as by the needs of capitalist development in South Africa (Bozzoli, 1983; Marks and Rathbone, 1982; Marks and Trapido, 1987). Despite this qualification, however, the criticisms levelled by subaltern and other scholars have called into serious doubt the continuing analytical usefulness of the concept of class in a southern African context. It may be seen, at best, as more amorphous and permeable than originally supposed, but the most stringent criticisms present it as a homogenising category misguidedly used by social analysts to impose extraneous meanings on to local cultures.

A wholehearted adoption of the latter perspective appears, however, to pose the danger of a new kind of misrepresentation. Large numbers of rural South Africans were drawn into the labour force, and the identities and ideas of social category which developed in the process are more likely to have drawn upon both indigenous perceptions and employment experiences than to have excluded the latter altogether. To use once again the example of the SABC ethnic music stations: the identities of the illiterate migrant workers who were their intended audience were expressed not simply through playing and listening to pure indigenous or 'traditional' forms but rather involved a syncretic mixture of these with 'pop' elements and with themes expressing the exigencies of an urban/industrial existence.

In this article I show that labour migrants based in South Africa's Northern Province ${ }^{1}$ conceptualise their identities-and differentiate them from contrasting ones-in terms which refer to work and material circumstances as well as to cultural factors like religion and political affiliation. In this process of on-going identity construction the performing and appreciating of the kiba genre play a central role.

\section{KIBA: SOME BACKGROUND}

$K i b a$ originated in a rural dance played on end-blown reed pipes (dinaka). It consists of a strictly observed central canon of tunes, each with its own characteristic drum pattern and dance, which feature the six-note scale and the descending melodic sequence considered to be characteristic of traditional northern Sotho music (Kirby, 1934; Huskisson, 1958). Its use of polyrhythm and call-and-response, its integration of individual pipe players in a broader melodic pattern through the technique of hocketing, and 
its encompassing of individual variation within a broader overall structural pattern, are features typical of traditional music from other parts of subSaharan Africa (Chernoff, 1979; Nketia, 1975). The male version of the genre acquired its characteristic uniform of Scottish kilts and its polished style, which derives from intensely competitive situations, during leisuretime Sunday performances in the compounds and later the townships inhabited by northern Sotho-speaking male labour migrants working on the Witwatersrand ${ }^{2}$ and around Pretoria. Despite the incorporation of these recent referents, however, and despite its performers' capacity to combine a heroic discourse celebrating the glorious past of independent chiefs with an ethos of modern soldierly behaviour deriving from experience of World War II (James, 1994a: 88-9), kiba has less eclecticism than most popular cultural forms: it has not taken on the ubiquitous three chords of the Wesleyan hymn, and its structure of endlessly repeated rhythmic and melodic cycles shows no sign of giving way to the finite song form or the four-square rhythmic patterns of Tin-pan Alley (Manuel, 1988: 22-3, 85-6, 108).

Women's kiba, equally traditional in melodic and rhythmic format, has only recently been classified alongside the male version. Based on rural precedents which were originally sung by young unattached women, its sudden fashionableness in rural and urban contexts during the 1970 s was accompanied by a switch of constituency from younger women to married matrons or the mothers of older children. Its basis in a sung (dikoša) rather than an instrumental rural genre (dinaka), allows more improvisation of lyrics and swifter adaptation of content to an urban migrant context. This in turn gives greater scope for individual composers, who nonetheless base their lyrical improvisations on older songs. The new female style in rural contexts is usually called lebowa rather than kiba, and is seen as belonging in a sphere of female activity easily discounted by men. In an urban context, however, female kiba, along with the male version, with which it shares a space and an audience, has become a central part of weighty and consciously maintained setšo (tradition) performed by the adults who form the pillars of the migrant community. Women's kiba uses but simultaneously subverts the heroic idiom of the men's genre to comment with critical and comical directness on the quality of contemporary socio-economic conditions in general, and on domestic relationships in particular (ibid.: 94).

The broader constituency of labour migrant performers in my study comprised three distinct groupings: male workers residing on the Witwatersrand but based in Sekhukhune, the reserve south-east of Pietersburg which incorporated the former heartland of the nineteenthcentury Pedi polity; male migrants' stay-at-home dependent wives or sisters who reside year-round in the same Sekhukhune area; and female labour migrants from the Leboa area farther north who have moved to the Witwatersrand more recently to find work (see map). The men all began to play kiba during their childhood in the Sekhukhune reserve. In the well established migrant trajectory which each has subsequently followed in order to support his wife and children, from initial compounded mine employment to less restrictive forms of labour, the genre has played a central role. For the dependent wives and sisters of such men there is also a continuity of performance. The new fashion of kiba or lebowa, although representing an 


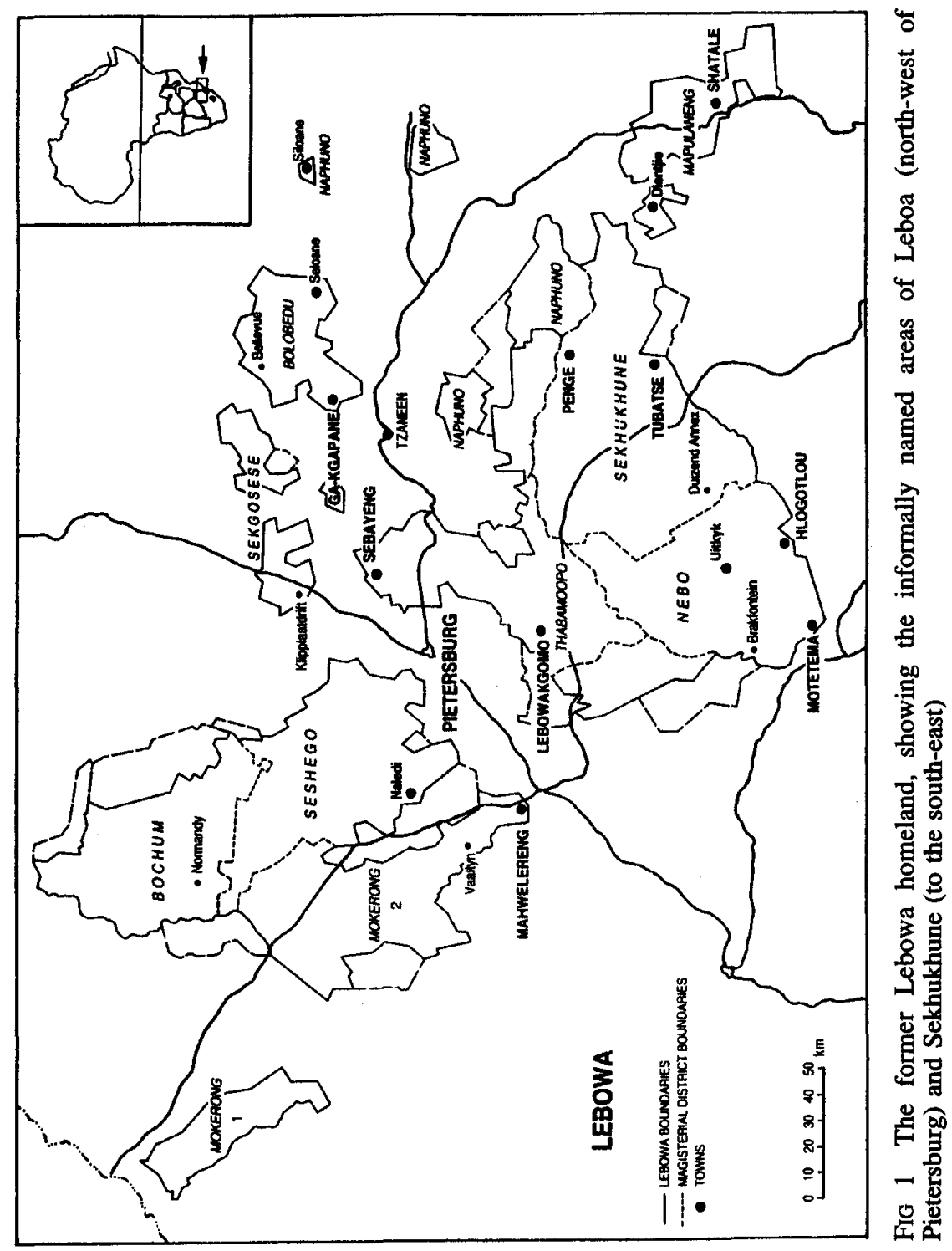


overlay upon their previous singing experience, dovetailed neatly with it. They have remained within the domestic domain, following the stages of a female life cycle and wearing clothes and singing songs which are classified as customary.

The female labour migrants who have recently joined male migrants' groups as co-performers have rather different origins. They grew up on freehold land, on white farms or in reserve areas farther north, and were driven, in the wake of physical relocation and social dislocation experienced by their families during the apartheid era, to find work as domestic servants on the Witwatersrand, in order to support their natal families and/or their own children. On the farms or freehold areas where they grew up, the influence of mission Christianity lent itself to a musical culture of adolescence which favoured choir, concert and church songs. Some sang traditional music only in childhood, while others learned to sing it and to dress in traditional dress only after arriving on the Witwatersrand. For these women from a diversity of rural homes, the style of music they learned did not signify, as it did for migrant men and their dependent women, a geographical and cultural continuity with a common home area. Rather, it represented an identity which, although constructed on the basis of a female performance culture borrowed from rural women, acquired its meaning in the context of a set of shared urban experiences.

In the article I use an example from each of these three constituencies to illustrate each of three claims. The first is that there are significant social divisions which are subjectively articulated in local terms, and that these articulations broadly correspond with-and probably provided some basis for-the classes discussed in detailed regional histories and anthropological studies in southern Africa. The second is that the terms describing these social cleavages are used more as conceptual tools than as labels for the actions or orientations of definite groups of people, since the categories undergo continual mediation and are perpetually breached. And the third is that this violation of categories through performance and through its reception by audiences broadens the field within which new identities can emerge and new communities imagine themselves.

\section{THE CONSTITUENCY OF KIBA: MIGRANT MEN}

Kiba is a performance genre belonging to a family of cultural practices and beliefs which are characterised as wa setšo ('of origin', traditional). Mmino wa setšo (music of origin: traditional music), previously more narrowly described as mmino wa sesotho (Sotho music), is the term increasingly favoured by rank-and-file performers, elites, promoters and radio/television presenters to characterise the musical family of which kiba is a part.

What gives the adjective wa setšo its content is, in part, its presumed links with a particular social constituency: a group of people thought of as concerning itself with things of origin or of tradition, and partly defined in opposition to a second group presumed to have no interest in such things. The categorical dichotomy pivots around mission Christianity and translates into English roughly as 'Christian/traditionalist'. In Northern Province communities these categories derive their existence historically from the 
acceptance or rejection of the Lutheran mission, with its eschewing of tribal initiation and its insistence that converts must transfer their social and even political allegiance from chiefs to the moruti (mission minister). Particularly in a heartland district like Sekhukhune which was the site of a powerful nineteenth-century African polity, this division manifested itself in extreme form, with Christians distancing themselves physically from chiefs and their subjects, and moving away to distant farms or mission stations (Delius, 1983: 160-78). Similar rifts existed even within reserve areas smaller and more remote from the former paramountcy. Many villages were, and some remain, physically and geographically divided between Christian and nonChristian sections (Mphahlele, 1971: 4; Sansom, 1991-92: 397-401).

Although the ruptures thus established within rural Northern Province communities were not altogether unprecedented, since those who accepted the mission way were often those who had already been marginal to society or disaffected with its leaders (Pauw, 1974: 427-8; Delius, 1983: 112-14), these rifts became newly conceptualised around the pivotal feature of Christianity. The resulting social categories were differently named, depending on the stance of the namer. Those proud to have affiliated themselves to the Christian way called themselves bakriste (Christians) and termed their opposites baheitene (heathens). Those aligning themselves with the chiefs called themselves baditshaba (those of the nation) in opposition to the derogatorily named majakane or majekane (Christians). ${ }^{3}$ The geographical divide which remains in many rural communities of the Northern Province is named in accordance with this latter usage: setshabeng is the section of the village where those of the nation are concentrated, and majekaneng is the place of the Christians. The paired terms majekane/ baditshaba and bakriste/baheitene, while orienting themselves by reference to a common dividing line, thus also imply opposing moral views of the division.

Similar social and conceptual divisions became entrenched through mission activity in a number of other southern African areas, particularly the eastern Cape and Kwazulu/Natal (Clegg, 1981; Hammond-Tooke, 1962: 63-5; Hunter, 1936: 351; Marks, 1986; Mayer and Mayer, 1961: 20-41; Meintjes, 1991; Reader, 1966: 338-42). It is in villages of the Northern Province that the division is particularly pronounced and has assumed a spatial aspect, however, in part because of the Lutheran missionaries' insistence on their converts' almost feudal subordination (Delius, 1983: 160-78) and on their abandoning of all aspects of 'indigenous culture' (Pauw, 1974: 427).

These dichotomous categories remain in current use. Whether or not they translate as classes is, however, ambiguous, since they are characterised in terms not primarily of socio-economic standing but rather of religious affiliation. But where they are used to describe individuals or groups of people, the terms describe not so much the current Christian/traditionalist divide as a categorisation which originally arose out of it. The makejane who are currently thought of as disparaging mmino wa seťso (traditional music) include both early immigrants to the cities who formed the ranks of the urbanised work force there and 'respectable' people living in the countryside who are self-employed in small businesses or who work in education and 
various branches of the civil service. The baditshaba from whom they distinguish themselves, while no longer necessarily-or purely-adherents of 'traditional' religion, are mostly low-paid migrant workers, residing near their places of urban or industrial employment but with strong links to a rural base which they visit frequently, to which they intend to return upon retirement from work, and which they regard as gae (home). Local discourses, while drawing attention to cultural identity and religious affiliation, thus point to socio-economic standing or class. (This is a class/ category division which, incidentally, corresponds more or less with the division between the two audiences mentioned earlier: the sophisticated fans of township jazz on the one hand and the poorer, rural-based group towards which radio jive was beamed.)

The story of Lucas Sefoka, a male migrant from the traditionalist stronghold of Sekhukhune shows how the performance of mmino wa setšo not only furnished a source of identity to migrants regarding themselves as part of the social category of baditshaba, but also gave them access to the support and succour of people from the same category who shared a common rural home.

Lucas Sefoka was born in 1944, in the setshabeng section of Sefoka village in Sekhukhune. Although his attending school for five years bore testimony to the fact that formal Western-style education was becoming available even beyond the domain of mission influence, a far more important aspect of his education as a nonChristian was his undergoing initiation in an age regiment together with baditshaba contemporaries. Shortly after completing the first stage of this extended ritual, he and others of his regiment left home to do harvest work for wages in the fields of nearby white farmers. Their departure, although described by him as 'running away from home', was a regular and expected part of the wild and unruly behaviour of baditshaba boys. While working on the farm they remitted small amounts of money to their parents, and returned home in between jobs for short periods to complete the last stages of initiation. After about five years of farm work Lucas Sefoka and his paternal cousin Philip Sefoka, again in accordance with expected practice, decided to travel by bus to Pretoria to look for better-paid jobs. Although they had not informed any of their relatives in Pretoria of their intention, and felt apprehensive about arriving unawaited in a big town, they were fortunate upon alighting from the bus to meet a man of the same initiation regiment who came from a neighbouring village. He took them to sleep in the backyard room of an old man from their home village, and had soon provided both with contacts with fellow villagers which gave them access to accommodation and domestic employment and which served to incorporate them into the local kiba club, which was one of a wide network of dance groups spread throughout the Witwatersrand.

When, a year later, Lucas left Pretoria to work in Johannesburg in an industrial job secured for him by his maternal cousin, he was shifted to the Alexandra branch of the kiba club SK Alex with all the speed and facility of a corporate transfer. When he was later disabled in an industrial accident, some relatives and fellow dancers accommodated him in a room in the yard where they lived in Alexandra, and he made a small living as a fruit vendor. Still later he found work as a gardener and became the leader of the Alexandra kiba club. ${ }^{4}$ 


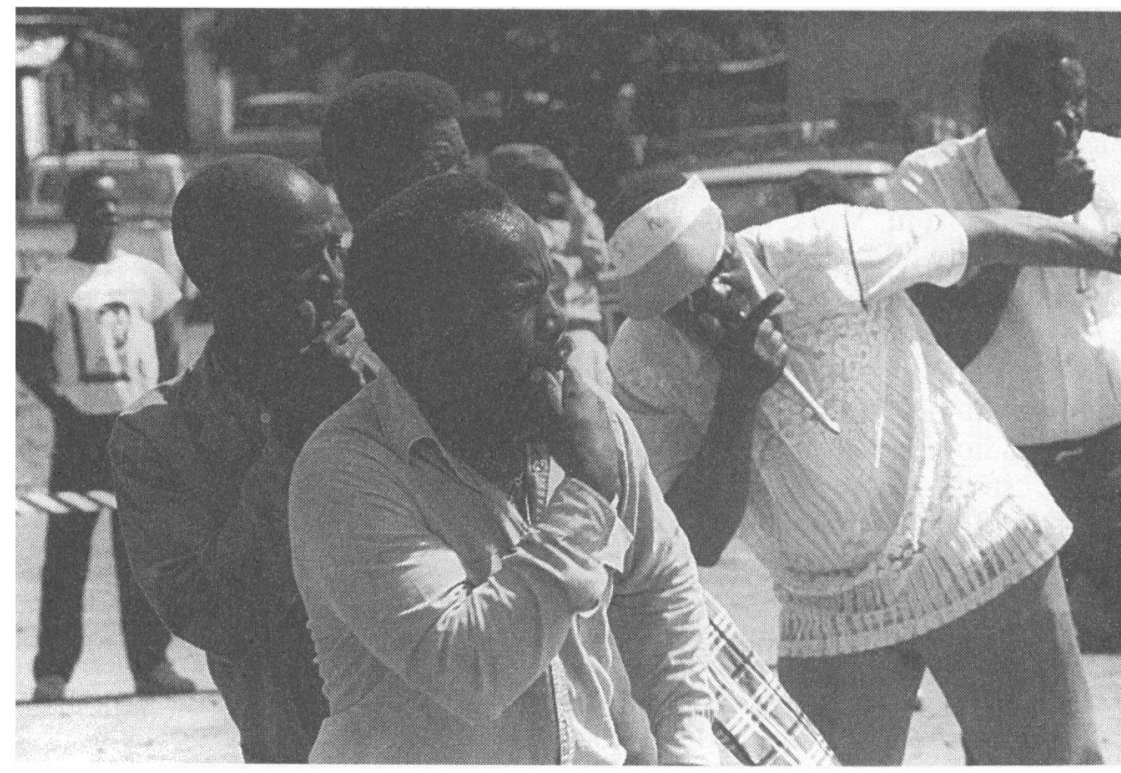

Plate 1 Men blowing dinaka: SK Alex, Alexandra township. (Photo by courtesy of Santu Mofokeng)

While many working men have, like Lucas, lived out their lives within the confines of groups of fellow baditshaba, it was not uncommon for migrants who achieved upward mobility to switch from one of these social categories to the other and to undergo a corresponding musical conversion. Although originally socialised by peers and parents into the rudiments of kiba performance, such men would cease their involvement as they began to mix primarily with people who considered this music socially inappropriate and thus of no aesthetic value. Some abandoned all involvement with the music. Others, though ceasing to be direct performers of $k i b a$, concerned themselves with its promotion.

A man who moved up through the ranks of the work force at his factory stopped being a dancer when he became the secretary of its recreational club, and assumed instead the duties of organising competitions between local dance teams and those representing other factories or mines. Another man, Piet Makola, was a poor-boymade-good who had achieved upward mobility through success in athletics. Inspired to apply a professional sporting model to the dance genre in which he had previously participated, he founded a co-ordinating body called the 'Mmino wa setšo Association'. The aim of this body, modelled on a football league, was to promote the financial rewarding and professionalisation of $k i b a$ performers and to encourage competition between different 'teams'.

Both these men, in assuming the role of organiser/patron, were including their aspiration to higher status, their social distance from the ranks of the music's performers and hence their remoteness from the social category of 
baditshaba. The insistence of informants that kiba is 'for baditshaba' indicates, then, not that this cultural form is oriented towards adherents of ancestral religion rather than Christians, but that its pool of performersparticularly male ones from traditionalist heartlands like Sekhukhune-consists of poor migrants rather than people from better-off backgrounds.

\section{SESOTHO AND SEKGOWA: STAY-AT-HOME WIVES}

In other contexts, however, the terms baditshaba and majekane are used not so much to categorise individuals or social groups as to refer to the cultural practices which those groups are thought of - not always accurately-as pursuing. To tie this specifically to the musical correlates of these contrasting sets of practices: baditshaba prefer to sing and listen to mmino wa setšo (traditional music), while majekane appreciate mmino wa kereke (church music) and the clothes and attitudes which go along with it. By an elegantly circular piece of definitional logic these categories, being defined by reference to the behaviour of their members, also provide the reference point by which the behaviour of their members is defined. It is, however, the clarity of the division between opposing kinds of musical taste, rather than the sharpness of the social division between Christians and non-Christians, which gives mmino wa setšo its specificity.

But in certain circumstances the starkness of the contrast between the social categories of baditshaba and majekane, rather than simply being

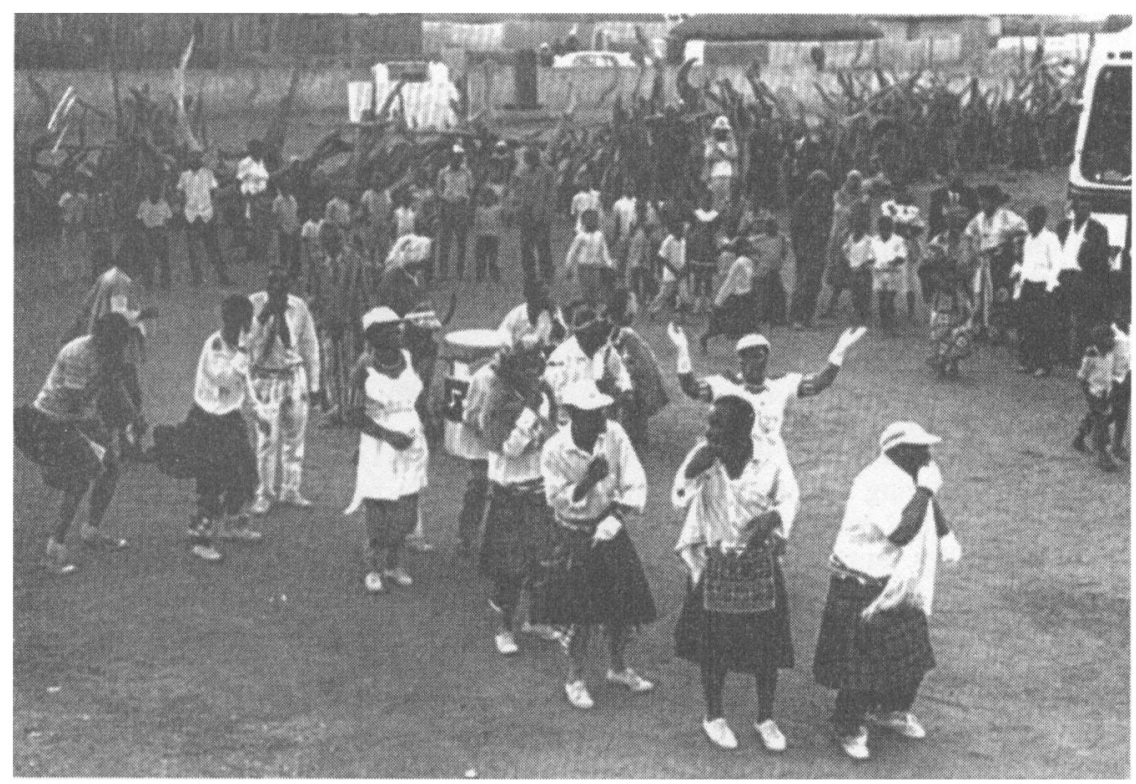

PLATE 2 SK Alex on a 'home' visit: arriving at Mamone, Sekhukhune. (Photo by courtesy of Santu Mofokeng) 
illustrated by the contrast between the presumed cultural practices of the respective groups, may be intensified by the cumulative addition of this cultural contrast. The tastes and behaviour of baditshaba-deferential behaviour, ways of sitting and fashions in clothing-are described as sesotho, while the preferences and behaviour of majekane, in contrast, are seen as emanating from and thus identified with sekgowa (the ways of whites).

The distinction between sesotho and sekgowa, in its counterpoising of tradition with modernity, has parallels in many other language communities of southern Africa (and beyond). ${ }^{6}$ The interest of analysts in these sets of categories has been viewed by some as involving a fruitless search for persistences of a pre-industrial world view (Spiegel, 1990: 46), but others have interpreted them as a device through which African people, by imagining their own past in complementary opposition to 'the ways of the European', have conceptualised their history as dominated but resilient subjects, and have formulated identities in the process (Comaroff and Comaroff, 1987: 193; Roseberry, 1989: 144, 201-3).

This is a worthwhile line of exploration but it could be taken further. Rather than merely demonstrating the unfolding of historical consciousness within an unspecified and amorphously defined cultural group, as some of these studies do, it would be more illuminating to explore the significance of these dichotomous categories in the lives of definite communities or individuals. My conversations with rural-based female kiba performers in a Sekhukhune village suggest that gender is a further differentiating factor which positions some people closer to one and some closer to the other side of the sesotho/sekgowa divide, and that the actions and contexts of performance, in particular, serve to bring the woman/man and the sesotho/ sekgowa dichotomies into alignment.

The singing group Dithabaneng (those from the place of the mountain), based in the village of Nchabeleng, was founded in 1976. Its members, drawn from three generations of women, had sung together since long before that date, and formalised their club's identity only after they had seen women from a neighbouring village perform the kiba style which was then beginning to sweep through the countryside. All live in the setshabeng section of the village; all for the purposes of performance wear characteristic sotho outfits consisting of headscarves, vests and lengths of cloth worn around the waist; most dress in sotho clothes when going about their everyday business as well.

The husbands (or, for the unmarried ones, brothers) on whom these women depend for a living are mostly baditshaba who have followed paths through the world of industrial employment and urban residence similar to that of Lucas Sefoka, described earlier. But although these women may share the status of baditshaba with their menfolk, their life histories and present circumstances reveal that they see themselves as 'more sotho' than men. Since childhood they have been identified more closely with home and with the domestic arena than their brothers, where it has been their place to keep house, reproduce proper social relation and hence do the work of sotho custom. They have worked beyond the village only in rural employment, and then only for short periods, while their brothers and husbands have spent years as labourers on the mines or in the city. And their minimal exposure to schooling has left them in all cases with less education than the male members of their families. 


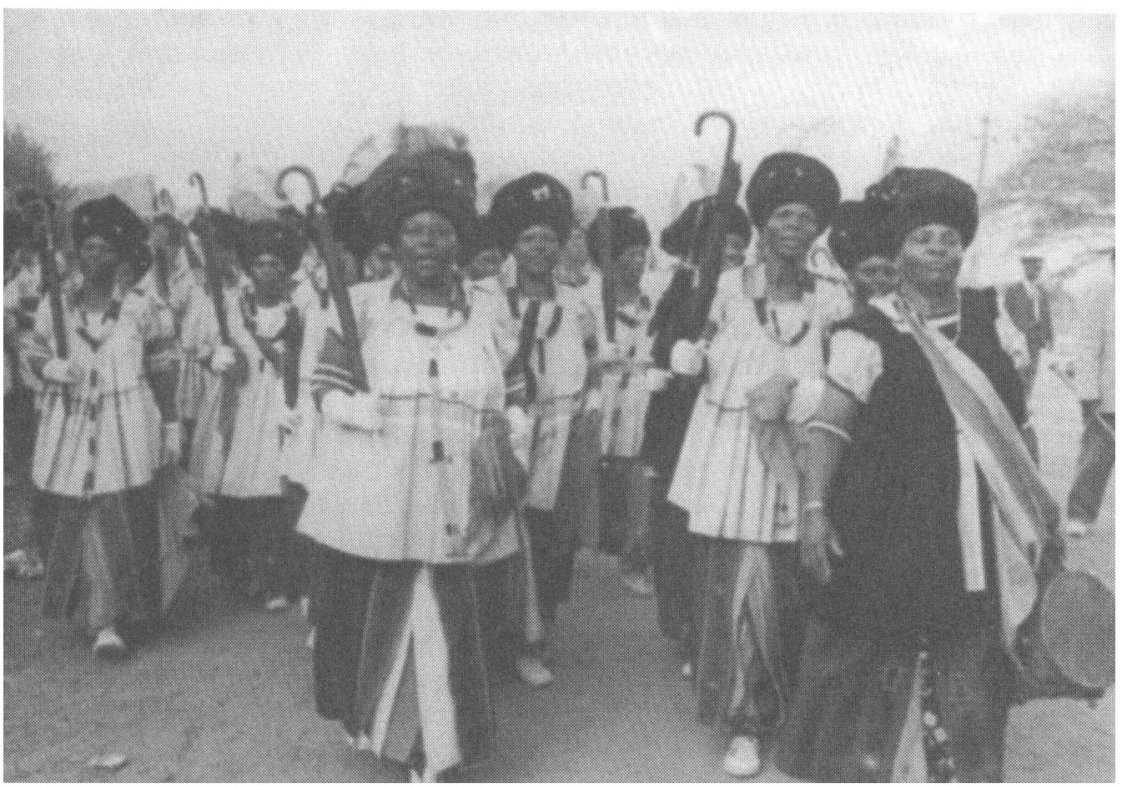

PLATE 3 Rural women singers performing to greet their urban visitors, SK Alex, at Mamone, Sekhukhune. (Photo by courtesy of Santu Mofokeng)

The divide between the ways of sesotho and those of sekgowa thus aligns not only with the divide between the social groupings of baditshaba and majekane but also with divisions of gender. Gender refines the classificatory schema and makes it more complex. But if we look in more detail at one of the group's members, Mmagoviolet Phakwago, we find that even the gender axes of this contrast are far from uncomplicated. Even among people who at first glance may appear to be baditshaba, even within a single family in that category, and indeed even if gender is taken into consideration, personal motivation may further differentiate people in such a way as to align some members closer to one and some closer to the other side of the sesotho/ sekgowa divide. Here it is only in the context of performance that these fine distinctions and subtle nuances are ultimately swept away, licensing women to unite under the rubric of sotho ways.

At the time of Mmagoviolet's birth in 1939 her parents lived in the majekaneng section of Nchabeleng village with her father's family. Most of her immediate neighbours were Christians, had attended school and were literate. But her father's social alignments, as a man who had been initiated and had not attended school, were more ambiguous. By the time her next sister, Mmagojunius, was born, her parents were 'no longer taking this [Christianity] seriously', and their move away from these kin to setshabeng (the section of the village inhabited by non-Christians) entailed so complete a neglect of the tenets of literacy that the date of birth of this second child was not even recorded.

Perhaps because of the early influence from literate people, Mmagoviolet set her sights on becoming schooled: an unusual ambition for a girl from this section of the 
village at the time. She was able to do so only by valiantly resisting her mother's demands that she should stay at home to tend the baby, but after three years the urgency of domestic duties became too great for her to withstand and she left school.

While her younger sister married a man 'of the nation' (moditshaba), Mmagoviolet's husband came from a background in which there was a mixture of mission and anti-mission influences similar to that in her own upbringing. His parents, too, had lived in majekaneng but although his father had been baptised his mother was a non-Christian, and they too moved to setshabeng after some time. Like Lucas Sefoka, he followed the normal trajectory for a youth from this section of the village. Unlike many of his contemporaries who resided in backyard rooms or compound employment while working on the Witwatersrand, however, he procured his own house in the township of Tembisa, where his wife lived with him for several years. Later, after being retrenched from his job as a factory worker, he established a small rural trading store, with a diversity of attendant enterprises such as pictureframing. Although they still live in setshabeng, and although neither he nor his wife has become a Christian, the modern orientation of their life style differs considerably from that of their neighbours and from that of the other members of the kiba club: it qualifies for the description sekgowa.

Perhaps the single most notable respect in which Mmagoviolet's cultural preference departs from this modern/Western orientation is her membership of the kiba club Dithabaneng to which her sisters and neighbours also belong, and her observance of sotho ways within the context of this group. Mmagoviolet's sense of marital duty dictated that she should live with and keep house for her husband in Tembisa, and in accordance with his preference she wears the dresses (diroko, from the Afrikaans rok) of sekgowa when in his company. But her preference is for the wearing of sotho clothes, and she values the solidarity and neighbourly support which are entailed in performing kiba with her fellow club members. They throw regular parties, hosted by each member in turn, at which each woman, irrespective of income, contributes a small amount of sorghum for brewing. The remaining expenses are paid out of the club's communal fund, which comes both from formal payment in return for performing and from a play-act in which women, dressing as policemen, 'arrest' men and fine them in a parody of the authoritarian behaviour of the South African police. The sense of sisterly fellowship experienced by members of this club during performance, although achieved only momentarily and in these specific circumstances, is powerfully felt and expressed in an idiom of undifferentiated female sotho-ness. ${ }^{\text {? }}$

Membership of social categories and adherence to the accompanying styles of cultural behaviour are thus neither static nor rigidly linked with gender. Within the life process of one family, different members may be oriented in a variety of ways, or the same members oriented differently over a period of years, with respect to these social and conceptual categories which nevertheless remain mutually exclusive and clearly distinguished from one another. A pattern can be perceived in which men are more inclined to adhere to, and thus influence their wives or sisters to adopt, the ways of sekgowa. But it is in the heightened context of performance, in particular, that village women use the idiom of undifferentiated sotho-ness to dramatise their sisterly solidarity and to negate momentarily the differences of wealth and status which divide them.

It may well be that these dichotomous categories have arisen through a community's imagining of its history as a stark juxtaposition between ways conceptualised as indigenous and those thought of as European. But it is in 
the dramatising of this juxtaposition by groups of specific social actors in a community - here, the dependent wives or sisters of male labour migrants who represent themselves as indigenes while type-casting their husbands or brothers as embodying the qualities of modernity - that the imagined history is made manifest.

By providing for the possibility of an all-encompassing allegiance to indigenous ways, musical performance can draw together even people from social categories or classes not normally associated with the genre in question. If this is true for the women of singing groups like Dithabaneng, it is even truer of the female labour migrants discussed in the third section of this article, and of the new audiences which are increasingly attracted to kiba.

\section{NATIONAL AUDIENCES AND WOMEN MIGRANTS}

The third point which I attempt to demonstrate in this article is that the breaching of social categories through performance and audience reception can provide scope for the creation of entirely new imagined communities. Evidence of this can be found, firstly and most obviously, if we return to the example of attempted media manipulation of the public with which the article began.

The period from 1940 to $c .1965$ saw the fostering of northern Sotho music: not only of live performance by mine managers looking for a way to contain the energies of their compounded labourers, but also of recorded performance by broadcasters such as the SABC's Yvonne Huskisson and by entrepreneurs employed by the recording company Gallo and its subsidiaries. While it is not impossible that these attempts to promote-and sell-traditional Sotho music were underpinned in part by apartheid ideology, financial gain provided at least as significant a motive. ${ }^{8}$ The profits yielded by this enterprise were disappointing, however, and it was eventually abandoned. The failure of attempts to record and distribute $k i b a$ may have been due in part to the unsuitability of the total performance event, with its dance, music and dramatic tableaux, to the format of recorded sound: the relatively greater popularity of the recordings made by SABC television in the late 1970s and 1980s certainly suggests that the genre is best apprehended in a multiplicity of ways rather than aurally alone.

Its popularity in this later era was not owed only to the enthusiasm of baditshaba, however, but can also be attributed to the fact that a broader revival of the genre, patronised by regional and national elites first in the Lebowa homeland government and later in the ANC, has captured the interest of majekane normally considered to be beyond its range. From churchgoers stopping in a street of Alexandra township to observe nostalgically the dancing which they once knew as children but have now moved beyond, through homeland ministers watching kiba at the opening of the Lebowa parliament, to teachers and political activists engaging dancers to celebrate the opening of a school or the anniversary of a women's federation in Soweto, the presence of groups of men and women kiba performers in their sotho gear frequently coincides with that of suited members of the middle class. Perhaps the most highprofile appearance of kiba dancers to date-and the starkest juxtaposition of customary dress with haute couture-was at the 1994 inauguration of President Mandela.

The collectivity at whom the messages and meanings of mmino wa setšo are directed is thus no longer the narrowly defined nation ( $t$ shaba) which evoked 
the loyalties of non-Christians but is expanding to incorporate all speakers of northern Sotho-even all South Africans-and thus to become a nation conceived of in more modern terms. The resulting imagined community may owe something to the manipulation of tradition mentioned earlier in this article. In much the same way that beneficiaries of the apartheid regime attempted to derive legitimacy by appropriating kiba's 'tradition' to their cause, members of the new government have identified dancing as a crucial part of what they are trying to define as a new culture-a process of patronising which, as in other parts of Africa, may unwittingly be aiding in this culture's fossilisation (Vail and White, 1991: 264-5).

But it is not only through deliberate orchestration that the revival of traditional music is proceeding and that broader audiences are being garnered. More spontaneous than organised has been the revival of kiba in Sekhukhune villages by youthful village 'comrades', the scourge of their elders at the height of apartheid's youth revolt, who now respectfully approach older migrants with requests for dancing lessons. At the opposite end of the scale, kiba clubs' performers have been incorporated into the global cultural phenomenon of 'world music', with the group Maaparankwe playing at venues in Europe and South East Asia. A new era has introduced a global audience to this local genre.

A further demonstration of the way in which the breaching of categories through performance provides a focus for the emergence of new identities is perhaps a less obvious one, and draws on the experience of the female labour migrants who began to appreciate and perform kiba in an urban context during the 1970s.

These dancers and their audiences, although laying claim to the legitimation of a common rural home as a basis for their involvement in this 'music of origin', had roots very different from those of their male labour-migrant dancing partners and from these men's dependent wives or sisters, and their choice of kiba as a performance genre appears at first sight very puzzling. Rather than hailing from the traditionalist heartland of the pre-colonial Pedi polity, these women and their families initially lived as tenants on white farms and black freehold land in the area north-west of Pietersburg known as Leboa, and later experienced the disruption of removal to the African homeland areas during youth or adolescence. Many of them grew up in communities of Christians and learned the music and performance culture thought of as appropriate to this social category. The apparent unity underlying the 'home' that they claim to come from is based rather on their common circumstances in town than on a shared geographical home in the country, and it was only when asserting their membership of this town-based 'home' that they partnered themselves with male migrants-people like Lucas Sefoka from Sekhukhune-and learned how to dance kiba.

In the case of these migrant women, the genre in a very real sense created a grouping, or performers and audience, around itself. If we seek an explanation for kiba's appeal to these women well beyond the limits of the baditshaba constituency, some clues are provided by two contributions to a recent book on African oral literature. In one, we are told that the capacity for oral performance is not merely the 'distinctive sign' of a given social condition, but is also a potential means of exerting pressure upon or of transforming social conditions and power relationships (Derive, 1996). 


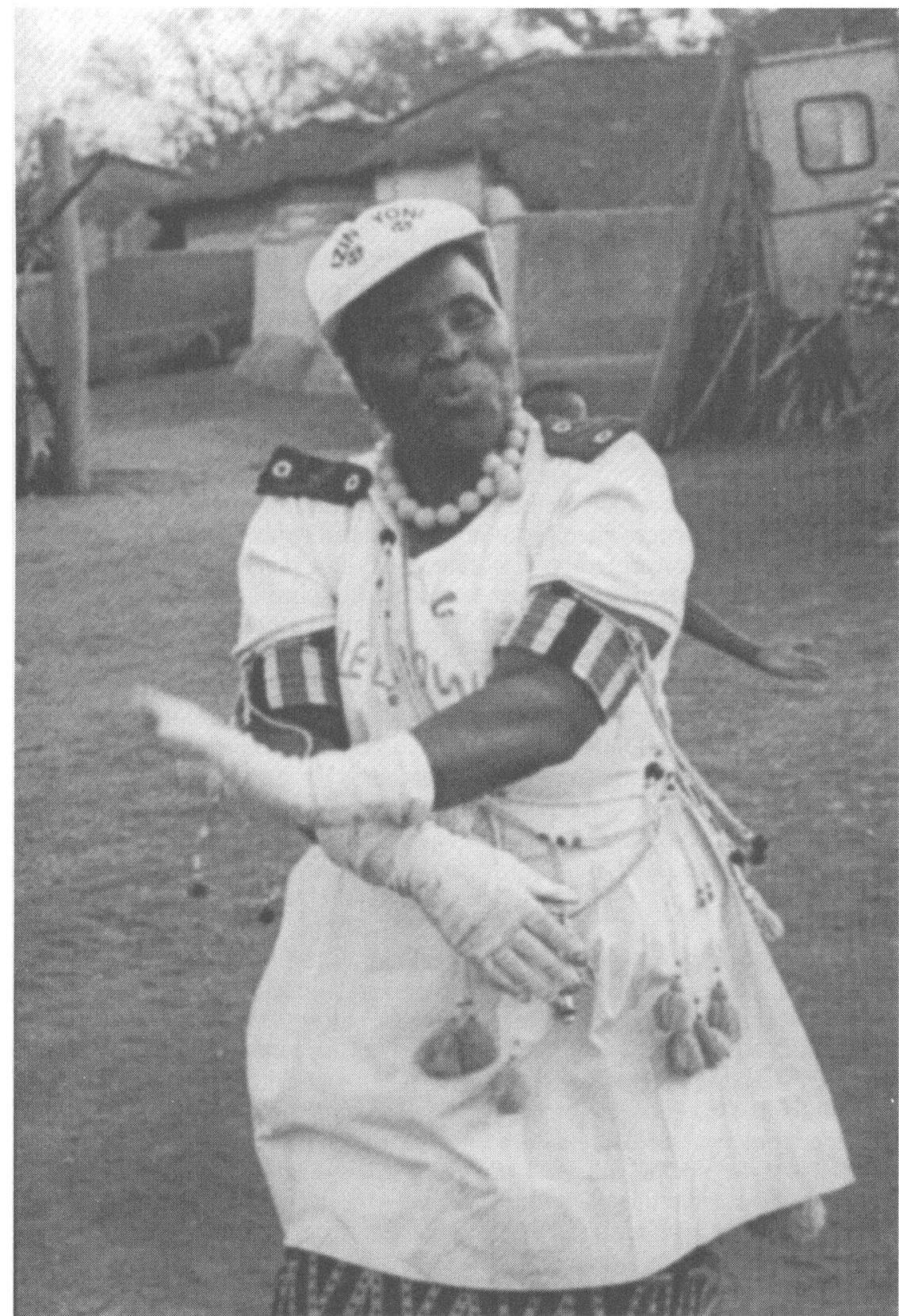

PLATE 4 Elsie Lekgotwane leading SK Alex in performance. (Photo by courtesy of Santu Mofokeng) 
Another indicates that, if a performance grips the intended listener with its praise or critical commentary, this is not simply because it provides an assessment of whether she plays her role appropriately within society's preordained framework. A performance's power lies rather in negotiating new meanings and outcomes, by creating new typifications of people and their roles, and by persuading the listener to accept both the typification and-in the process - the moral standpoint of the performer (Furniss, 1996).

If we apply these explanations to kiba we find that the lyrics alone-with their combination of men's celebration of the heroic past of independent chiefdoms and women's wry comments on contemporary domestic relationships-cannot explain the strength of this new source of identification. But, in the broader performance context, lyrics combine with dance and music to embody a life and a specific view of morality which men and women labour migrants have recreated for themselves. Their emphasis on sesotho or setšo, far from repeating past practices in the present or echoing country practices in town, activates a new world of experience which bridges the gap between town and country, past and present. It also bridges the gap between the genders which is highlighted in the rural women's version of the genre discussed earlier. The appeal of this migrant genre to people beyond its original pool of performers and audience lies not merely in its capacity to generate moral authority in lyrical terms but also in its power to embody a view of good relations by which others-even those far beyond its target audience-may measure themselves (James, 1997).

For migrant women, this recreation of identity had something of the quality of a cultural revival. It was thus not altogether different from the use of $k i b a$ by the media, television and the national bourgeoisie. For them as for these other constituencies the genre did not simply reach a target audience of workers or traditionalists: it spilled over to encompass a series of wider groupings.

\section{CONCLUSION: CATEGORY AND CLASS REVISITED}

In conclusion, it is instructive to revisit the question of whether the concept of social class is valid in Third World contexts. Its usefulness has been called into question because of its basis on an essentially Western, modernising view of social change. Since modernity was delivered to such countries 'only in an extremely travestied form by the mad and violent agency of imperialism' (Chakrabarty, 1989: 225), the argument goes, it would have provided but a shaky foundation for the development and emergence of capitalist-style social classes. In other words, although social change automatically occurs in the process of industrialisation, such change would not necessarily have resulted in the emergence of a unitary working class driven forward by enlightened notions of its own liberation if there were no undistorted models of modernity for such an emergent class to follow.

From the evidence presented in this article it should be clear that indigenous notions of class or social category are articulated in the Northern Province but that their pivotal characteristics are not altogether local in origin. While the loyalty to traditional authorities implied by the term baditshaba has an indigenous core, the focal feature of Christianity implied 
in its opposite term, bakriste, has not. The fact that the original meaning or content of these social categories did derive, at least partly, from an outside/ European source, may seem to thwart the enterprise of uncovering a local concept of social category or class. But it should be borne in mind that the central distinction between the two classes, although exotic in the sense that it takes Christianity as a pivotal feature, is in another sense local, since it sets up a kind of idealised 'indigenous way' in opposition to Christianity by starkly counterpoising the two. This, then, is a concept of social category or class which is both 'local' and 'imported': it is as 'syncretic' as the popular culture forms through which it has been expressed (Barber, 1987).

The visions of the modern way upon which these categorisations are founded may be shaky ones, then, but the stark juxtaposing of Christians with traditionalists and of European with indigenous ways does nevertheless contain a certain historical logic. The juxtaposition has a basis in nineteenthcentury history, having been founded in the twin processes whereby some accepted the Christian mission and rejected the political authority of the chiefs while others repudiated the mission and developed intensified loyalty to traditional authorities. In heartland communities, like the ones in Sekhukhune from which our first two examples were drawn, twentiethcentury history can throw further light on the logic of this division. Communities in the area put up a fierce resistance-centred on memories of the nineteenth-century Pedi polity-to apartheid planners' attempted restructuring of local governance and land use. The imperative of resistance, having been articulated largely from within the ranks of labour migrants or baditshaba (Delius, 1989, 1990), dictated that allegiance to the local way remain strongly distinguished from allegiance to the Christian way well into the 1950s. The strength of the contrast, surviving into the present day, also perhaps serves the more subjective historical purpose of enabling people to represent their past to themselves (Comaroff and Comaroff, 1987).

But in the northern areas from which migrant women performers originate the basis for a conceptual division of this kind is less obvious. There is evidence, in fact, that, if a concept or culture of 'working class' exists in these areas at all, it is based largely on attendance at school, on the desired or actual use and consumption of market items such as lounge suits, hi-fis and clothes, and on attendance at church, especially the Zionist Christian Church, whose headquarters are situated in the area and which has been characterised as solidly peasant-proletarian in its membership (Comaroff, 1985). When the female migrants in my sample were growing up their predominant form of musical performance was makwaya, a choral form which originated in mission-based African middle-class communities but which has spread to working-class ones and is now widely sung in schools as well as in churches.

In these areas and communities, if there is a distinction between baditshaba and majekane, it has been confused and blurred by the largescale movements directly and indirectly occasioned by apartheid. Many families originally living under backward tenant conditions on farms moved to the African reserves or homelands to be nearer the schools, churches and shops by whose proximity they measured their steps towards material progress. Others, having moved reluctantly from the relative independence of Christian African freehold farming to these reserves, represented their 
new circumstances as a retrogression. But, whether the move was viewed as a forward or a backward step, the cultural environment of these northern reserve villages was one in which the mixture of customary with modern elements did not undermine the ultimate value placed upon civilisation (tlhabologo).

The distinction between categories made in this context was often very fine. Rather than drawing a sharp contrast between two dichotomous classes, it stressed and dramatised fine differences within an upwardly aspirant working class by applying measurements to such valued qualities as 'respectability' (cf. Bozzoli with Nkotsoe, 1991) or 'civilisation' (thabologo).

It is against this backdrop that one must understand female migrants' strategy of aligning themselves with the baditshaba from whose ranks the core performers and audiences of traditional music had previously been drawn. Through becoming involved in this genre, they earned the right to be heard in the male-dominated world of labour migration, and won legitimacy as performers and lyrical commentators which was denied to the protagonists of the equivalent rural female genre, lebowa. As independent groups of dancers in loose alliances with men, they have achieved a voice more audible than that accorded them in the Zionist Christian Church to which many previously belonged, or in the patriarchally structured burial societies to which many continue to pay their dues. The traditionalism of their chosen form of expression thus represented neither a denial of their hard-earned autonomy as wage-earners nor an undermining of the aspiration to modernity which had signposted their families' movements during the apartheid era. Their involvement together with their male dancing partners in the creation of a distinct migrant moral economy allowed the bridging of gaps between past and present, town and country, men and women, Christian and traditionalist.

\section{ACKNOWLEDGEMENTS}

I gratefully acknowledge assistance from the Witwatersrand University Research Committee and Mellon Fund, the CSD, and the assistance and support of the Institute of Advanced Social Research (formerly the African Studies Institute), Witwatersrand University. Thanks to Patrick Pearson, Isabel Hofmeyr, Adam Kuper, Liz Gunner, Sam Nchabeleng and Karin Barber for comments on drafts, and to the participants in seminars at Birmingham University's Centre of West African Studies and at London University's Institute of Commonwealth Studies for their helpful suggestions. Thanks to Malete Thomas Nkadimeng and the late Philip Mnisi for help with interpreting, and to Rob Allingham for making his early recordings of kiba available.

\section{NOTES}

${ }^{1}$ At the time of research the home areas of these people comprised parts of the former Lebowa homeland.

2 The Witwatersrand (Afrikaans: ridge of white waters), recently renamed Gauteng (Sotho: place of gold) is one of the main gold-mining areas of South Africa, and stretches from Springs in the east, through Johannesburg to Randfontein in the west.

${ }^{3}$ Contemporary folk accounts give various origins for this term: one said it derived from the missionaries' insistence that women cover their breasts by wearing jackets, while another claimed that it came from the Afrikaans $J a$, maar kan nie ('Yes, but [I] can't'), a derogatory 
reference to Christian converts' readiness to claim moral superiority while being unable to stick to the stern tenets of their faith.

${ }^{4}$ Lucas Sefoka, recorded discussion with Deborah James and Malete Thomas Nkadimeng, Johannesburg, 2 May 1990.

${ }^{5}$ Piet Makola, recorded discussion with Deborah James and Malete Thomas Nkadimeng, Edenvale, 7 July 1990.

${ }^{6}$ Setswana/segoa among speakers of SeTswana; xintu/xilungu for Shangaan; isiketwisilungu for SiNdebele. See also Coplan (1987, 1991); Ferguson (1992). For communities elsewhere see Thomas (1992), Roseberry (1989).

${ }^{7}$ Mmagoviolet Phakwago, recorded discussion with Deborah James and Philip Mnisi, Nchabeleng, 17 July 1991.

${ }^{8}$ Personal communication, Rob Allingham and Lucky Monama, both of Gallo Africa.

\section{REFERENCES}

Ballantine, C. 1989. 'A brief history of South African popular music', Popular Music 8 (3), 305-10.

-1993. Marabi Nights: early South African jazz and vaudeville, Johannesburg: Ravan Press.

Barber, K. 1987. 'Popular arts in Africa', African Studies Review 3 (30), 1-78.

Barnard, S. 1989. On the Radio: music radio in Britain. Milton Keynes: Open University Press.

Bozzoli, B. 1983. 'Marxism, feminism and South African studies', Journal of Southern African Studies 9 (2), 139-71.

- with M. Nkotsoe. 1991. Women of Phokeng: consciousness, life strategy and migrancy in South Africa, 1900-83. Johannesburg: Ravan Press.

Chakrabarty, D. 1989. Rethinking Working-class History: Indian jute workers in Bengal, 1980-40, Princeton, N.J.: Princeton University Press.

Chambers, I. 1986. Popular Culture: the metropolitan experience. London: Methuen.

Chemoff, J. M. 1979. African Rhythm and African Sensibility: aesthetics and social action in African musical idioms. Chicago: University of Chicago Press.

Clegg, J. 1981. 'The music of Zulu immigrant workers in Johannesburg', in Papers presented at the First Symposium on Ethnomusicology. Grahamstown: International Library of African Music.

Comaroff, J. 1985. Body of Power, Spirit of Resistance: the culture and history of a South African people. Chicago: University of Chicago Press.

Comaroff, J. L. and J. 1987. 'The madman and the migrant: work and labour in the historical consciousness of a South African people', American Ethnologist 14 (2), 191-209.

Coplan, D. 1979. "The African performer and the Johannesburg entertainment industry: the struggle for African culture on the Witwatersrand', in B. Bozzoli (ed.), Labour, Townships and Protest. Johannesburg: Ravan Press. 1985. In Township Tonight: South Africa's black city music and theatre. Johannesburg: Ravan Press.

-1987. 'Eloquent knowledge: Lesotho migrants' songs and the anthropology of experience', American Ethnologist (19) 3, 413-33.

1991. 'Fictions that save: migrants' performance and Basotho national culture', Cultural Anthropology 6 (2), 169-92.

Delius, P. 1983. The Land Belongs to Us: the Pedi polity, the Boers and the British in the nineteenth-century Transavaal. Johannesburg: Ravan Press.

-1989. 'Sebatakgomo: migrant organisation, the ANC and the Sekhukhuneland revolt', Journal of Southern African Studies 15 (4), 581-615. 
1990. 'Migrants, comrades and rural revolt: Sekhukhuneland, 1950-87', Transformation 13, 2-26.

Derive, J. 1996. 'The function of oral art in the regulation of social power in Dyula society', in G. Furniss and E. Gunner (eds.), Power, Marginality and African Oral Literature. Cambridge: Cambridge University Press.

Erlmann, V. 1991. African Stars: studies in black South African performance. Chicago: University of Chicago Press.

Ferguson, J. 1992. 'The country and the city on the Copperbelt', Cultural Anthropology 7 (1), 80-92.

Furniss, G. 1996. 'The power of words and the relation between Hausa genres', in G. Furniss and E. Gunner (eds.), Power, Marginality and African Oral Literature. Cambridge: Cambridge University Press.

Hamm, C. 1987. Review of D. Coplan, In Township Tonight (1985), Popular Music $6(1), 353-5$.

Hammond-Tooke, W. D. 1962. Bhaca Society: a people of the Transkeian uplands. Cape Town: Oxford University Press.

- (ed.). 1974. The Bantu-speaking Peoples of Southern Africa. London: Routledge.

Hunter, M. 1936. Reaction to Conquest: effects of contact with Europeans on the Pondo of South Africa. London: Oxford University Press, for the International African Institute.

Huskisson, Y. 1958. 'The Social and Ceremonial Music of the Pedi'. Unpublished Ph.D. dissertation, Johannesburg: University of the Witwatersrand.

James, D. 1994a. 'Basadi ba baeng/the women are visiting: female migrant performance from the northern Transvaal', in E. Gunner (ed.), Politics and Performance in Southern Africa, Johannesburg: Witwatersrand University Press. 1994b. 'Mmino wa setšo: songs of town and country and the experience of migrancy by men and women from the northern Transvaal'. Unpublished $\mathrm{Ph} . \mathrm{D}$. thesis, Johannesburg: University of the Witwatersrand.

1997 'Anthropology, history, and the making of past and place', African Studies 56 (2) (forthcoming).

Joyce, D. 1995. 'The end of social history?' Social History 20 (1), 73-91.

Kirby, P. 1934. The Musical Instruments of the Native Races of South Africa. London: Oxford University Press.

La Hausse, P. 1993. 'So who was Elias Kuzwayo?' in P. Bonner, P. Delius and D. Posel (eds.), Apartheid's Genesis. Johannesburg: Ravan Press.

Manuel, P. 1988. Popular Musics of the non-Western World: an introductory survey. Oxford: Oxford University Press.

Marks, S. 1986. The Ambiguities of Dependence in South Africa: class, nationalism and the state in twentieth-century Natal. Baltimore, Md: Johns Hopkins University Press.

Marks, S., and Rathbone, R. 1982. 'Introduction' to S. Marks and R. Rathbone (eds.), Industrialisation and Social Change in South Africa. London: Longman.

Marks, S., and Trapido, S. 1987. 'Introduction' to S. Marks and S. Trapido (eds.), The Politics of Race, Class and Nationalism in Twentieth-century South Africa. Harlow: Longman.

Mayer, P. and I. 1971. Townsmen or Tribesmen. Cape Town: Oxford University Press.

Meintjes, L. 1996. Review of Christopher Ballantine, Marabi Nights (1993), Popular Music 15 (2), 246.

Meintjes, S. 1991. 'Family and gender in the Christian community at Edendale, Natal, in colonial times', in C. Walker (ed.), Women and Gender in Southern Africa to 1945. Cape Town: David Philip. 
Middleton, R. 1986. Studying Popular Music. Milton Keynes: Open University Press.

Mphahlele, E. 1971. Down Second Avenue. Harmondsworth: Penguin.

Nketia, J. H. K. 1975. The Music of Africa. London: Gollancz.

Pauw, B. 1974. 'The influence of Christianity', in W. D. Hammond-Tooke (ed.), The Bantu-speaking Peoples of Southern Africa. London: Routledge.

Reader, D. H. 1966. Zulu Tribe in Transition. Manchester: Manchester University Press.

Roseberry, W. 1989. Anthropologies and Histories: essays in culture, history and political economy. New Brunswick, N.J.: Rutgers University Press.

Sansom, B. 1991-92. 'Song and political opposition in Sekhukhuneland, 1961-62', Anthropological Forum 6 (3), 393-427.

Spiegel, A. D. 1990. 'Cohesive cosmologies or pragmatic practices?' Cahiers d'études africaines 117 (XXX-I), 45-72.

Thomas, N. 1992. 'The inversion of tradition', American Ethnologist 19 (2), 213-32.

Vail, L., and White, L. 1991. Power and the Praise Poem: southern African voices in history. London: James Currey.

\section{ABSTRACT}

This article uses a case study of the kiba migrant performance genre from the Northern Province of South Africa to illuminate recent theoretical ideas on the role of performers and audiences, and in so doing to offer a critical perspective on the way in which the concept of class has been conceptualised in some southern African studies. While the homogenising and Western-derived concept of class may well be unsuitable in some African and other southern contexts, as certain writers have claimed, migrant northern Sotho communities have developed indigenous notions of social category which combine modern work-related sources of identity with apparently backward-looking celebrations of traditional behaviour. The article examines the contention of performance theory that cultural expression does not merely reflect the predilections of established groupings of people but may provide a focus for the consolidation and identity of new ones.

\section{RÉSUMÉ}

Cet article se sert d'une étude de cas sur le kiba, un genre de spectacle nomade provenant de la province du nord de l'Afrique du Sud, pour illuminer des idées théoriques récentes sur le rôle des artistes et des spectateurs afin d'offir une perspective critique sur la manière par laquelle le concept de classe a été conceptualisé dans quelques études africaines. Tandis que l'homogénéisation du concept de classe dérivé de l'ouest puisse très bien être peu appropriée dans certains contextes africains et autres contextes du sud, comme certains écrivains l'ont prétendu, les communautés migratoires du Sotho du nord ont développé des notions indigènes de catégories sociales qui combinent des sources modernes d'identité liée au travail avec apparemment des célébrations arriérées d'attitudes traditionnelles. Cet article examine l'assertion de la théorie du spectacle que l'expression culturelle ne reflète pas tout simplement les prédilections de groupes de gens établis mais peut fournir un centre d'attention pour la consolidation et l'identité de nouveaux groupes. 